\title{
Public Debt Sustainability in Ethiopia
}

\author{
Abiy Serawitu \\ Dire Dawa Management and Kaizen Institute, Dire Dawa, Ethiopia
}

\begin{abstract}
The main objective of this study is to examine whether public debt in Ethiopia is sustainable or not. The study used 20 years time series data from 2000/01 to 2o20/21 to explain debt sustainability, using graphical , Dickey Fuller test of stationary, and fiscal approach of debt sustainability analytical analysis of literatures. As a result of which, it was found that Debt to GDP ratio is unstable or inconsistent over a long period of time .From 2002 to 2009 the ratio exhibited a continuous decline rate where as from 2009 to 2020 revealed relatively an increasing trend.The study also aimed to forecast future values debt to GDP ratio using AR(1) time series forecasting model As a result of regression prediction , the future values have shown a declining trend from 2021/22 onwards Most country's experience have shown as a rule that country's debt-to-GDP ratio climbs, the higher its risk of default becomes and governments strive to lower their debt-to-GDP ratios. In Recent years (2015 to 2020) it was found that the country's Debt to GDP ratio continuously mounted from $54 \%$ to $61 \%$ as compared to the previous years. From this one can deduce that debt serving will compromise the development of the country and hence its debt serving will affects growth by crowding out social spending of the country.
\end{abstract}

Keywords: Debt sustainability and AR(1)

DOI: $10.7176 / \mathrm{DCS} / 11-5-03$

Publication date:May $31^{\text {st }} 2021$

\section{Introduction}

The relationship between external debt sustainability and economic growth has drawn significant concentration from researchers and policymakers after the global debt crisis in the early 1980s. Now days, the growth of public debt for many developing and developed countries has raised the concerns about the impact of domestic public debt on economic growth and the government's capability to serve its debt obligations without detention the future and target rates of economic growth. The critical reason of external debt in developing countries is to fulfill lack of "saving investment" gap (Adelman \& Chenery1966).

The developing countries facing with a current account deficit were encouraged to borrow from developed countries as well as an international community to make better their economic growth. Gohar et al. (2012) recommended that countries take debt from the external sources for many reasons that are their income is low; with budget deficit or they are having low investments. In addition, Soludo (2003) asserted that countries borrow for two broad categories; macroeconomic reasons or to finance the transitory balance of payments deficits aimed at boosting economic growth and reduce poverty. This study, therefore discusses the issue of debt sustainability in relation to economic growth

External debt is one of the main challenges faced by the developing countries. Gohar et al. (2012) mentioned that the repayment or «debt service» creates problems for many countries especially for developing countries because a debt has to be serviced are more than the actual amount it was taken for. Either, it drains out limited resources and restricts financial resources for domestic need of development of these countries.

A country's public debt is considered sustainable if the government is able to meet all its current and future payment obligations without exceptional financial assistance or going into default. Sustainability of public debt can be broken down into short and long term sustainability. Short term sustainability targets that fiscal and budgetary policies must respond instantly to avoid excessive growth of indebtedness. If long term debt sustainability should be a time horizon far enough to identify the impact on state budget and commitments on the loans Câmpeanu, (2007).

\subsection{Statement of the Problem}

Many studies have been conducted about public debt sustainability and economic growth in different scenarios in the world. Most of them used different Debt sustainability analytical approaches. Among others include ,graphical and test of stationery approaches, Solvency approach, physical approaches ,debt over hung hypothesis, external approaches, human development approaches and IMF and the World Bank perspectives Likewise, the relation between debt sustainability and economic growth are also studied, using CGE model, time series analysis and VAR model .However common findings and understandings about unlike empirical studies and theoretical issues are less studied. Moreover, different reports have also exhibited that Ethiopia is subjected to debt over hung condition and risk of debt distress is high .Thus, this .study is intended to fill the aforementioned gaps by rationalizing descriptively and by considering 20 years debt to GDP ratio of Ethiopia. 
1.2. General Objective of the study is to examine debt sustainability and forecast future values Specific objectives

- To evaluate forecasting values of debt to GDP ratio in Ethiopia

- To examine whether debt is sustainability or not in Ethiopia

\section{Literature Review}

\subsection{Concept and definition of Debt sustainability}

One of the most difficult tasks in preparing a poverty reduction strategy consists in setting priorities for public action, taking into account the cost of social programs and the capacity of the government to pay that cost. The ability to pay for social programs essentially is determined by the resources available to the government through taxation and/or loans getting the loan, the country should meet its debt service requirements out of current income, otherwise, the creditors have two choices. They can finance the country, lending at a predictable loss in the hope that the country will ultimately be able to repay its debt after all; or they can forgive, reducing the debt level to one that the country can repay. On the contrary, as debt grows, the country decided debt servicing to be financed through inflationary measures, increasing tax base, punitive taxes and printing of money, this in turn crowding out investment. Thus, the issues of debt sustainability are a key for economic development. (Gunter \& Wodon 2008).

External borrowing as a policy to promote economic growth is currently creating a serious debate among economists and policy makers. The key concern is whether or not external borrowing leads to economic growth in debtor countries. This debate results in two main perspectives for explaining the relationship between external debt and economic growth. On one hand, the Neoclassical and the Endogenous growth models advocated that there is a positive relationship between external debt and economic growth. They highlighted that debt is one of the sources for financing capital formation, and if financing capital formation through this means impact positively on investment, it could promote economic growth (Siddiqui 2002 and Adesola 2009).On the other hand, among other scholars Krugman contradict this view by mentioning external debt as one of the factors hampering economic growth ( Krugman 1988). Kalonji explained that heavy external debt is the cause of poverty in the debtors' country while Chongo noted that public debt is a double edged sword (Chongo 2013).

Debt Sustainability is defined as the ability to maintain a constant debt-GDP ratio over a period of time. Sustainability is challenged when the debt to GDP ratio reaches an excessive value. Kasidi and Makame( 2013) thought that, a number of factors come into play when establishing if a country is able to service its debt. These factors include the existing debt stock and associated debt service, the prospective path of its deficits, the financing mix of the debt and the evolution of its repayment capacity in terms of foreign currency value of GDP, exports and government revenue. A country's public debt is considered sustainable if the government is able to meet all its current and future payment obligations without exceptional financial support or going into default. Analysts look at whether policies needed to stabilize debt are feasible and consistent with maintaining growth potential or development progress.

\subsection{Debt sustainability analytical approaches}

\subsubsection{Fiscal approach ( Fiscal reaction function)}

When a country defaults on its debt, it often triggers financial panic in domestic and international markets alike. As a rule, the higher a country's debt-to-GDP ratio climbs, the higher its risk of default becomes. Although governments strive to lower their debt-to-GDP ratios, this can be difficult to achieve during periods of unrest, such as wartime, or economic recession. In such challenging climates, governments tend to increase borrowing in an effort to stimulate growth and boost aggregate demand. This macroeconomic strategy is a chief ideal in Keynesian economics.

Economists who adhere to modern monitory theory (MMT) argued that sovereign nations capable of printing their own money cannot ever go bankrupt, because they can simply produce more fiat currency to service debts. However, this rule does not apply to countries that do not control their own monetary policies, such as European Union (EU) nations, who must rely on the European Central Bank to issue euros.

\subsubsection{External approach}

Ley (2004) is derived mathematically how debt to GDP ratio is sustainable or decline, as follows:

The basic debt relationship over time is given by the following equation: $\mathrm{D}_{\mathrm{t}}^{\mathrm{f}}=\left(1+\mathrm{it} \mathrm{f}^{\prime}\right)_{\mathrm{Dt}^{-}}-1 \mathrm{f}^{*}-\left(\mathrm{NICA}_{\mathrm{t}}+\right.$ $\left.\mathrm{Tr}_{\mathrm{t}}\right)-\mathrm{FI}_{\mathrm{t}}+$ DNFA (1)

where, $\mathrm{D}^{\mathrm{f}}$ as the total foreign debt stock, which is both public and private; $\mathrm{f}^{*}$ as the average nominal interest rate on total foreign debt; NICA* as the noninterest current account, except for current transfers; $\operatorname{Tr}$ as the sum of official grants and other current transfers; FI as the non-debt-creating.

With a few assumptions and relatively simple algebra applied to equation

(1), Ley showed that changes to the debt-to-GDP ratio over time will adhere to the following "law of motion 
$\Delta \mathrm{dt}=\left(\frac{\mathrm{rpt}-\mathrm{gt}}{\mathrm{rt}-+\mathrm{gt}}\right) \mathrm{dt}-1-$ nica $* \mathrm{t}$

(2) debt is stable or decline if the following mathematical

Relations holds true nica $* \mathrm{t}>=\left(\frac{\mathrm{rpt}-\mathrm{gt}}{\mathrm{rt}-+\mathrm{gt}}\right) \mathrm{d} \mathrm{t}-1$

\subsubsection{Debt overhang hypothesis}

Debt overhang defines as the presence of an accumulated debt sufficiently large that creditors do not expect with confidence to be fully repaid (Krugman 1988). Alternatively, it refers to a debt burden so large that an entity cannot take on extra debt to finance future projects.

Debt overhang occurs when an excessive debt stock introduces negative externalities in the economy beyond the transfer of resources, first on investment and adjustment and then on economic growth. This is because high current and future debt transfers lead to anticipation by domestic and foreign investors of future higher taxes and increased uncertainty, both of which create a disincentive effect on the present investment or adjustment decisions of an indebted country. The concept of "investment" has to be viewed broadly here. It refers to accumulation in human capital through spending on education and health care as well as in physical capital, such as machinery and infrastructure. It also captures many types of policy reforms, including structural reforms and macroeconomic stabilization, whose long-term benefits may come at the expense of short-term costs

\subsubsection{Solvency Approach}

Solvency approach to DSA enables to estimate a sustainable fiscal stance at a particular moment in time on the basis of a definition of the fiscal deficit, which refers to the consequence of a fiscal year and its matching annual borrowing requirements. On the other hand, governments do not finance their expenses entirely with their annual income. As an alternative, they shift spending between periods to meet annual fiscal targets. To analyze the medium and long run sustainability of the fiscal policy, it is required to judge the financing constraint facing the public sector in a long-term dynamic context. Looking at the government budget constraint from this inter temporal viewpoint introduces the concept of long-term "solvency." Even if the government faces substantial fiscal deficits and high today, the government can be considered solvent as long as resources generated in the future are sufficiently large to cover all future debt-service obligations. The borrower may experience a "liquidity" problem, but lenders should not worry too much about current debt-servicing problems if they are prepared to revolve over current debt-servicing obligations.

\subsubsection{Debt Sustainability from a Human Development Perspective}

An essential alternative approach is frequently referred to as the human development approach to debt sustainability and debt relief. This approach prioritizes the MDGs instead of conventional debt sustainability, and it states that even if a country has the resources to pay its contractual debt service, current debt service might crowd out public spending of resources needed to reach substantial poverty reduction or the achievement of the other MDGs. As such, debt sustainability is defined as that level where debt service no longer crowds out MDGpriority public spending. This introduces a thought of affordable debt service linked to the MDGs, and the notion is translated into an argument supporting debt relief if possible in terms of debt-service relief. clearly, reducing debt service can benefit the recurrent expenditure budget directly.

In most LICs, if countries postulate the existence of a recurrent-fiscal gap, applying this alternative debt sustainability concept might be very effective in relaxing this gap. In put into practice, the approach can be operational in many diverse ways. The crowding-out effect on priority spending by debt service could be minimized by establishing upper limits on debt-service ratios (debt service related to government revenue or GDP). One prominent proposal along these lines was suggested by Birdsall and Williamson (2002). Another was founded in a Catholic Agency for Overseas Development (CAFOD) article by Northover, Joyner, and Woodward (1998), and extended by Berlage et al. (2003). We describe below the basic algebra of this approach.

\subsection{6 . IMF and the World Bank four Steps Necessary to Conduct a DSA}

The four critical steps required to conduct DSA already is operational at the IMF and the World Bank (IMF 2002; IMF and IDA 2005) are follows:

1. Deciding on the appropriate debt sustainability concepts and indicators.

2. Conducting consistent analysis of the debt dynamics based on the chosen menu of indicators, under a most-likely benchmark scenario, over a medium-to-long-term period.

3. Running stress tests using a number of detailed alternative scenarios, taking into account the most relevant structural vulnerabilities of the economy.

4. . Translating debt sustainability into borrowing policies

\section{Research methodology}

3.1. data type and Methods of data analysis :

The study will use both descriptive and econometric time series model analysis using STATA software of 
version 14. Descriptive analysis is simply used to examine the characteristics of debt to GDP ratio of time series data over time from $2000 / 20$ to $2020 / 21$. Whereas, econometrics analysis is used to forecast future values of the data under investigation

Likewise, the study is also used Meta analysis strategy to find out common findings and understandings about debt sustainability issues and its role in economic development, based on reviewing different theoretical and empirical literatures. Secondary source of data collected from country economy .com will be employed for the purpose of analysis.

\section{Econometrics model and definition of variables}

This study will intend to use one of the time series forecasting models ( AR(p) ,MA(q) or ARIMA (p,d,q) ) depending on the patters of ACF and PACF

- $\quad \operatorname{AR}(p): y t=b o+b 1 y t-1+b 2 y t-2+\ldots+b p y t-p+\varepsilon t$, where $\varepsilon t$ is white noise. $y t$ as predictor's ofd debt to GDP. We refer to this as an an autoregressive model of order ( AR (p) )model, an autoregressive model of order $\mathrm{p}$.

- $\quad \operatorname{MA}(q): y t=\mu+\varepsilon t+b 1 \varepsilon t-1+b 2 \varepsilon t-2+\ldots b q \varepsilon t-q$, where $\mu$ is the mean of the series, the $\theta 1, \ldots, \theta q$ are the parameters and the $\varepsilon t, \varepsilon t-1, \ldots, \varepsilon t-q$ are white noise( error terms). The value of $q$ is called the order of the moving average MA model

- $\quad$ An ARIMA model is one where the time series was differenced at least once to make it stationary and combine the AR and the MA terms.: $\operatorname{ARIMA}(\mathrm{p}, \mathrm{d}, \mathrm{q}$,$) : yt =$ bo + b1yt- $1+\mathrm{b} 2 \mathrm{yt}-2+.+$ bpyt-p $+\varepsilon t+\mu+\varepsilon t$ $+\mathrm{BO} 1 \varepsilon \mathrm{t}-1+\mathrm{B} 2 \varepsilon \mathrm{t}-2+. . \mathrm{Bq} \varepsilon \mathrm{t}-\mathrm{q}$

\section{Analysis and Interpretation}

\subsection{Descriptive analysis}

Table1.The distribution of Debt and Public Debt to GDP ratio in Ethiopia from 2000/01-2020/2021

\begin{tabular}{|l|l|l|l|}
\hline Year & Debt to GDP (\%) & Year & Debt to GDP (\%) \\
\hline $2000 / 01$ & 93.63 & $2012 / 13$ & 42.18 \\
\hline $2001 / 02$ & 97.33 & $2013 / 14$ & 47.50 \\
\hline $2002 / 03$ & 107.36 & $2014 / 15$ & 47.55 \\
\hline $2003 / 04$ & 103.69 & $2015 / 16$ & 54.46 \\
\hline $2004 / 05$ & 103.10 & $2016 / 17$ & 54.87 \\
\hline $2005 / 06$ & 78.24 & $2017 / 18$ & 57.72 \\
\hline $2006 / 07$ & 67.87 & $2018 / 19$ & 61.11 \\
\hline $2007 / 08$ & 42.40 & $2019 / 20$ & 57.72 \\
\hline $2008 / 09$ & 38.53 & $2020 / 21$ & 55.26 \\
\hline $2009 / 10$ & 35.19 & & \\
\hline $2010 / 11$ & 39.61 & & \\
\hline $2011 / 12$ & 45.33 & & \\
\hline
\end{tabular}

Source: Country economy .com

As shown in table 1 above, debt to GDP ratio is maximum in 2002(107.36\%) indicating that the country is less likely will pay back its debt and the higher its risk of failure to pay as compared to other years Similarly, minimum ratio in $2008(35.19 \%)$ revealed that the country has relatively high ability for serving its debt.(Goldstein 2003). A sustainable government debt is one in which that debt ratio is constant over a period of time or falling over time; a rising debt ratio denotes unsustainable. Sustainability is challenged when the Debt to GDP ratio reaches an excessive value. Following to this, the descriptive result above disclosed that Debt to GDP ratio is unstable or relatively increasing over time from 2000/01 to 2020/21. Thus, public debt in Ethiopia is not sustainable. For instance, results above illustrated that debt to GDP ratio is relatively increasing from 2009/10 t0 $2020 / 21$, revealed that Ethiopia is subjected to difficulty to service its debt in the future, hence the debt became unsustainable.

Other alternative way to examine debt sustainability in relation to economic growth refers to the presence of debt overhang - defined as the negative effect of a large debt burden or an ever increasing Debt to GDP ratio over time, on economic growth, which its debt serving affects growth by crowding out social spending. A study by the World Bank found that countries whose debt-to-GDP ratios exceed $77 \%$ for prolonged periods, experience significant slowdowns in economic growth: every percentage point of debt above this level costs countries $1.7 \%$ in economic growth. most literatures also revealed that high public debt subjected a country for higher debt interest payments, crowding out effects of investment, vulnerable to capital flight and higher interest rates Likewise, more recently (IMF 2013) defined debt sustainability and its role in economic development as the country's ability and willingness to meet current and future debt service obligations in full, without alternative to debt rescheduling and without comprising growth. In the same token, 
Fig 1.Trend of Public Debt to GDP ratio of Ethiopia

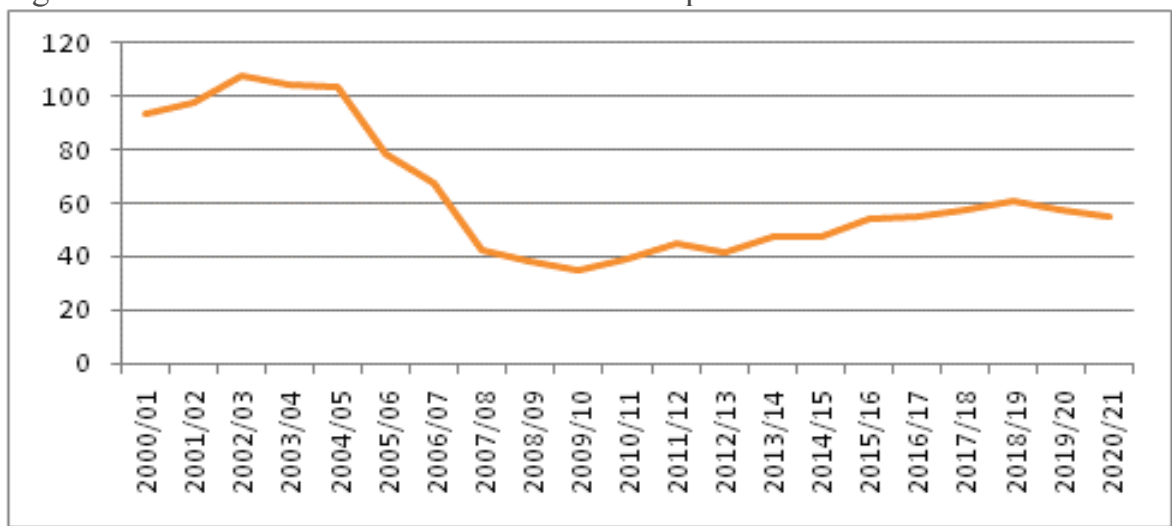

From fig 1 above, it can easily be seen that Debt to GDP ratio is continuously declined from 2002/03 to $2009 / 10$.Where as relatively increased from 2009/10 to 2020/21. In other words, the ratios are not constant or stable over a long period of time. In a nut shell, from this one can justify the failure of debt sustainability in Ethiopia.

\subsection{Econometric Analysis}

Since the data under investigation is time series data, it is compulsory to check whether it is stationery or not before starting any analysis .Using Dickey Fuller test of stationary, the original data is found to be insignificant. Here under it can be seen that, ' $Z(t)$ ' value is -1.185 which is a small negative number (as compared to ' $z(t)$ ' for 'debt to GDP) and p-value is also found insignificant (0.9135) at all levels of significant. Thus, null hypothesis of Dickey Fuller test of unit root is not rejected. Therefore, the original time series data is non stationary .

Similarly, first differencing is not found to be stationary at all levels of significant (but only at 5 and $10 \%$ levels ) and $p$ value is significant (0.0033). Whereas, the second differencing is significant at all levels of significant and the $\mathrm{p}$-value is 0.000 .Therefore, the null hypothesis of Dickey Fuller test is rejected and hence the second differencing make the time series data is more stationary .

Fig 2.Trend of debt to GDP at second differencing

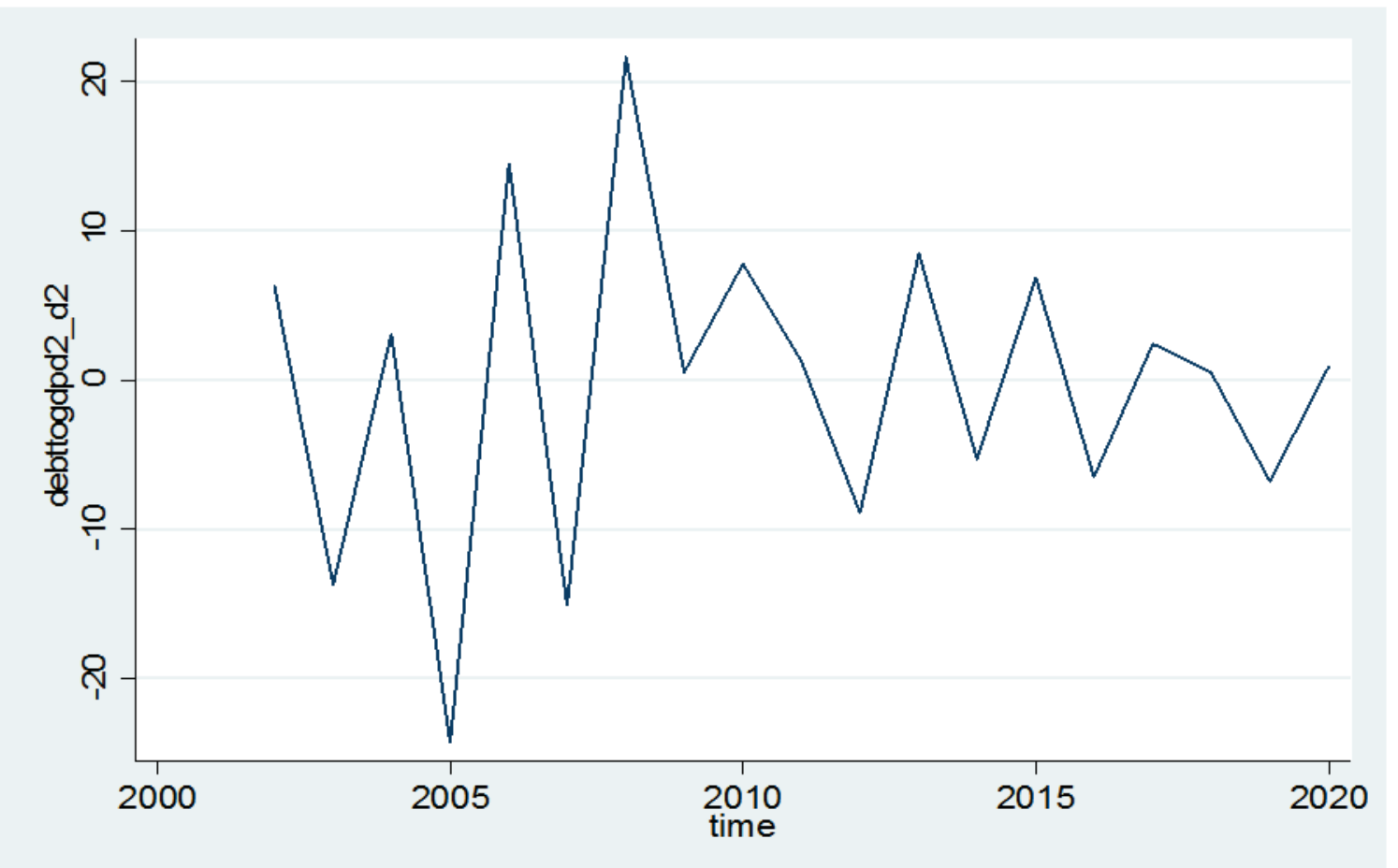

Fig 2. above revealed that trend of debt to GDP ratio has a constant mean and variance over time. Whereas, the original time series data do not exhibit similarly 
Table 2. Dickey Fuller test of stationary

\begin{tabular}{|l|l|l|l|l|l|}
\hline Data type & Test statistics & $1 \%$ critical value & $\begin{array}{l}5 \% \text { critical } \\
\text { value }\end{array}$ & $10 \%$ critical value & $\begin{array}{l}\text { Mackinnon } \\
\text { value }\end{array}$ \\
\hline Original data & -1.185 & -4.380 & -3.600 & -3.240 & 0.9135 \\
\hline first diff. & -4.286 & -4.380 & -3.600 & -3.240 & 0.0033 \\
\hline Second diff. & -8.942 & -4.380 & -3.600 & 3.240 & 0.000 \\
\hline
\end{tabular}

Pattern and values of PACF and ACF are also examined as to decide the type of time series forecasting model and the order itself As indicated below in table 3 , ACF is moving in a sine wave pattern .whereas PACF significant spikes at the firs lag. The pattern revealed that the forecasting time series model is auto regressive of order one $(\mathrm{AR}(1))$

- corrgram gdp_d2, laga (18)

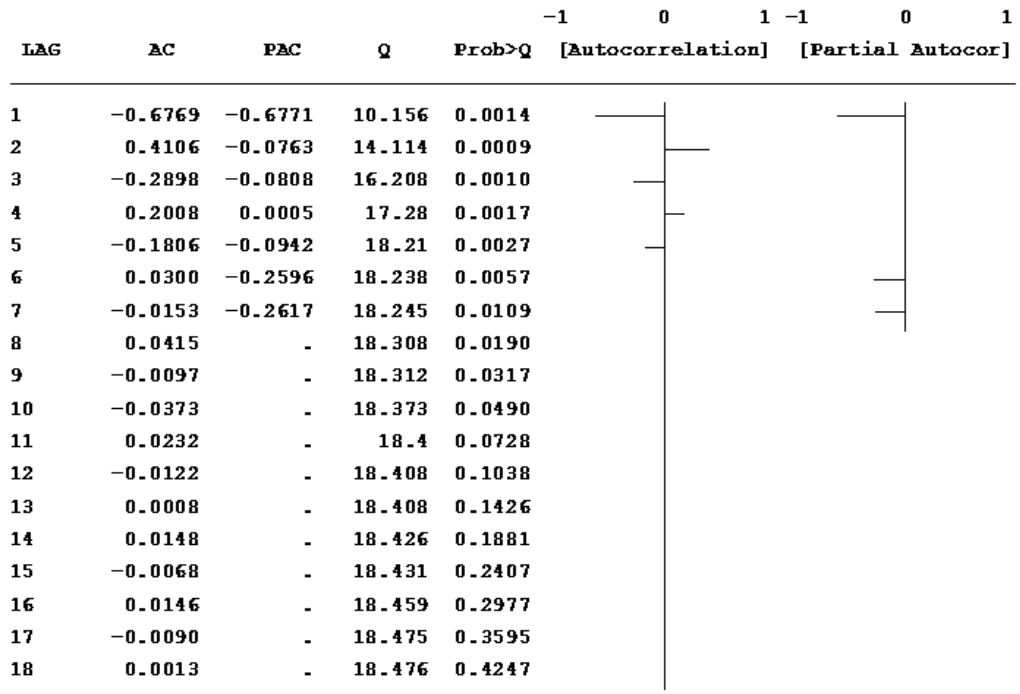

The regretion analysis of AR of order one model (AR (1): yt =bo +b1yt-1 +et ) output exhibited that the goodness-of-fit of the model is significant ( prob. $>\mathrm{F}=0.0019$ ). Likewise, the coefficient of the first lag value is found to be 0.677 and the p-value is 0.002 (significant at $1 \%$ level of significant) .Similarly, Durbin test for autocorrelation (serial correlation) revealed do not reject the null hypothesis of no serial correlation (p-0.81)

\begin{tabular}{|l|c|l|}
\hline Variables & Coefficients & $\mathrm{P}>\mid \mathrm{t}$ \\
\hline Coff.of first lag & 0.6678 & 0.002 \\
\hline Cons. & 0.96 & 0.78 \\
\hline Adj R-squared & 0.46 & \\
\hline Prob $>$ F & 0.0019 & \\
\hline Root MSE & 14.85 & \\
\hline
\end{tabular}

The predicted model for AR(1):yt $=-0.96+0.677 \mathrm{yt}-1$. At $2021(\mathrm{t}=22)$, and $\mathrm{y}-21=55.26$ the forcating value is 36.45 ,At $2022(\mathrm{t}=23), 23 . .72$

\section{Summary of findings}

Based on theoretical and empirical literature review, descriptive findings and time series model analysis the following major findings are worth drawn:

- Recent 10 years result of Debt to GDP ratio is unstable or relatively increasing over time from 2009/10 to $2020 / 21$.

- debt to GDP ratio is maximum in 2002(107.36\%) indicating that the country is less likely will pay back its debt and the higher its risk of failure to pay as compared to other series of years .Similarly, minimum ratio in 2008 (35.19\%) revealed that the country has relatively high ability for serving its debt.(Goldstein 2003)

- debt to GDP ratio is relatively increasing from 2009/10 t0 2020/21, revealed that Ethiopia is subjected to difficulty to service its debt in the future, hence the debt became unsustainable.

- AR(1) forcating model exhibited that debt to GDP ratio will have a declining trend from 2021/22 on wards in Ethiopia

- Literatures have shown that an increasing Debt to GDP ratio over time will affects the country's economic growth, by crowding out social spending (investment), vulnerable to capital flight and 
higher interest rates,

- The 20 years graphical analysis of debt to GDP ratio revealed that the mean and variance are not constant and hence, it is not stationery

- Studies have shown that debt to GDP ratio is not a one -fit -all indicator to measure debt sustainability .Literatures confirmed that if debt ratio is stable or decline over time, then debt is sustainable.

- Literatures have also shown that a higher effect of debt on growth. But the magnitude of the effect varies considerably across countries

- Most literatures have shown that high indebtedness can trigger a decline in new flows of external resources, leading, in turn, to a reduction in poverty-related spending. As debt grows, so does the possibility that its servicing will be financed through inflationary measures, punitive taxes, arbitrary spending cuts, or other distortional policies

- One alternative way to define debt sustainability refers to the presence of debt overhang- defined as the negative effect of a large debt burden on economic growth. which its debt serving affects growth by crowding out social spending

- The standard approach to debt sustainability analysis focuses on the debt-to-GDP ratio revealed that Public debt has the potential to increase liquidity in the economy, improve consumption patterns, and improve citizens' wellbeing, which ultimately decreases the burden of borrowing. At the same time, the rise of debt to higher levels can compromise a country's welfare, especially if it crowds out private investment and limit government expenditure on health, education and other key public infrastructures, and which in turn leads to lower economic growth

- Akyüz (2010 mathematically) showed that growth rate, real interest rate of domestic debt, weighted average of domestic and external debt and exchange rate are the critical factors affecting the stability or decline of debt sustainability Accordingly, the factors have a pivotal role in determining the economic growth by stabilizing debt sustainability.

- Most study also confirmed that growth rate, exchange rate, interest rate, non-interest current account balance and ratio of the primary balance are critical factors affecting debt sustainability

- Most study revealed that high public debt subjected a country for higher debt interest payments, crowding out effects of investment, vulnerable to capital flight and higher interest rates .

- Studies similarly indicated that, in the case of external debt, when interest payments on the debt are due, money flows from the domestic economy to foreign countries, and external debt has a greater burden on the economy than internal debt.

- Studies also explained that, real interest rates on government debt frequently fall below the growth rate of real GDP, implying the public debt provides real resources that governments can use to finance government expenditures. Studies also revealed that lower productivity growth will actually decrease the cost of serving public debt, while the slower population growth worsens the cost of servicing the debt. By contrast, a reduction in risk will also raises interest rates and increase the cost of servicing the debt.

- Most literatures grouped country's ability to continue serving debt without hampering economic growth as a stable. A country with a high debt-to-GDP is similarly grouped as trouble paying off public debts, which are any balances owed to outside lenders. In such scenarios, creditors are apt to seek higher interest rates when lending. Extravagantly high debt-to-GDP ratios may discourage creditors from lending money altogether.

- $\quad$ studies showed that poorest countries have an unsustainable debt simply because they have more urgent needs to reduce poverty than to make debt-service payments

- Debt overhang effect is stronger in countries with policies and institutions of weak quality, and with lower aid flows.

\section{CONCLUSIONS}

Based on summery of findings and objective of the study, the following key conclusion is worth drawn:

Graphical trend analysis of public debt to GDP ratio in Ethiopia is not sustainable. Firstly because, the graph exhibited comparatively an increasing trend from 2009/10 to 2020/21 and a decreasing trend from $2010 / 11$ to $2008 / 09$. Secondly as, according to Dickey Fuller test of stationary, unit root or non stationary is not rejected. Whereas, the forcating values of debt to GDP ratio have shown a declining trend from $2001 / 22$ on wards.

From literatures, it is concluded that most indebted country's provide due attention to more their urgent needs to reduce poverty than to make debt-service payments to attain debt sustainability. On the contrary, the creditor attracted to provide voluntary new lending when the indebted country's debt is not large enough. 
Similarly, most country's experience in the literature have also shown as a rule that the higher country's debt-to-GDP ratio climbs, the higher its risk of default becomes and governments strive to lower their debt-toGDP ratios, this can be even more difficult to achieve sustainability during periods of unrest, such as wartime, or economic recession. In such challenging environment, governments tend to increase borrowing in an effort to stimulate growth and boost aggregate demand.

On the contrary, increased borrowing tends to raise the growth rate of real GDP up to some threshold level, and consistently high government deficits tend to have negative effects on real GDP growth and price stability. Literatures also revealed that, if the government decided to finance debt serving through inflationary measures, like printing of money and punitive taxes, then it crowding of investment and in turn results in negative impact on economic growth

Likewise, most studies have also recommended that fiscal reforms are mandatory and policies should be adopted to maintain an increasing growth-interest rate differential for debt to remain stable or decline in future. More importantly, monitoring and taking immediate caution by running a sufficiently large noninterest current account surplus as possible when real interest rates on government debt frequently fall below the growth rate of real GDP.

\section{Reference}

Adelman, I., \& Chenery, H. B. (1966). The foreign aid and economic development: the case of Greece. The Review of Economics and Statistics, 1-19.

Akyüz, Y. (2010). Debt sustainability in emerging markets: a critical appraisal (Vol. 28). Third World Network (TWN).

Alcidi, C., \& Gros, D. (2018). Debt Sustainability Assessments: The state of the art. European Parliament

BOHN, H. 2007. Are stationary and cointegration restrictions really necessary for the intertemporal budget constraint? Journal of Monetary Economics, 54, pp. 1837-47

Bökemeier, B., \& Stoian, A. (2018). Debt sustainability issues in Central and East European countries. Eastern European Economics, 56(5), 438-470.

Buiter, W. H. (1995). Macroeconomic policy during a transition to monetary union.

.. Chatterjee, S., Gibson, J., \& Rioja, F. (2017). Optimal public debt redux. Journal of Economic Dynamics and Control, 83, 162-174.

Chenery .B and Strout A.M. (1966), Foreign Assistance and Economic, American Review, 56(4), (1966), 679733

Claessens, Stijn. 1990. “The Debt Laffer Curve: Some Estimates.” World Development 18 (12): 1671-77

Cohen, Daniel. 1985. "How to Evaluate the Solvency of an Indebted Nation." Economic Policy 1: $139-67$.

Cuddington, J. T. (1997). Analyzing the Sustainability of Fiscal Deficits in Developing Countries, Word Bank. Policy Research Working Papers, Economics Department Georgetown University, Washington DC, 20057-1045

Cuddington, J. T. (1999). Analyzing the sustainability of fiscal deficits in developing countries. The World Bank.

El-Mahdy, A. M., \& Torayeh, N. M. (2009). Debt sustainability and economic growth in Egypt. International journal of Applied Econometrics and quantitative studies, 6(1), 21-55.

Galí, J., \& Perotti, R. (2003). Fiscal policy and monetary integration in Europe. economic policy, 18(37), 533572.Galí, J., \& Perotti, R. (2003). Fiscal policy and monetary integration in Europe. economic policy, 18(37), 533-572..

Gohar, N. A. Bhutto and F. Butt (2012). The Impact of External Debt Servicing on the growth of Low-Income Countries, Sukkur Institute of Business Administration. In Proceedings of 2nd International Conference on Business Management (ISBN: 978-969-9368-06-6).

Goldstein, M. (2003). Debt sustainability, Brazil, and the IMF. Institute for International Economics Working Paper, (03-1).

Gunter, B. G., \& Wodon, Q. (2008). Analyzing Debt Sustainability.

Guzman, M., \& Heymann, D. (2015). The IMF debt sustainability analysis: issues and problems. Journal of Globalization and Development, 6(2), 387-404.

Hostland, D., \& Karam, P. D. (2006). Assessing debt sustainability in emerging market economies using stochastic simulation methods (No. 2005-2226). World Bank Publications. Jayme Jr, F. G. (2001). External debt sustainability: Empirical evidence in Brazil. Texto para discussão, 154.

Hostland, D., \& Karam, P. D. (2006). Assessing debt sustainability in emerging market economies using stochastic simulation methods (No. 2005-2226). World Bank Publications.

IMF, I. (2005). Operational Framework for Debt Sustainability Assessments in Low-Income Countries-Further Considerations. Washington DC: FMI.

IMF, W. (2006). Review of Low-Income Country Debt Sustainability Framework and Implications of the MDRI. Washington DC: FMI. 
International Monetary Fund (2011) "Modernizing the Framework for Fiscal Policy and Public Debt Sustainability Analysis." Prepared by the Fiscal Affairs Department and the Strategy, Policy, and Review Department, approved by Carlo Cottarelli and Reza Moghadam

Krugman, P. (1985). International debt strategies in an uncertain world. International debt and the developing countries, 79-100.

Krugman, P. (1987). Prospects for international debt reform. UNCTAD, International Financial Issues for the Developing Countries, Geneva.

Krugman, P. R. (1988). Financing vs. forgiving a debt overhang (No. w2486). National Bureau of Economic Research.

Mahmood, T., Rauf, S. A., \& Ahmad, H. K. (2009). Public and External Debt Sustainability in Pakistan (1970s-2000s). Pakistan Economic and Social Review, 243-267.

Makin, A. J., \& Pearce, J. (2014). How sustainable is sub-national public debt in Australia?. Economic Analysis and Policy, 44(4), 364-375.Beqiraj et al. (2018)

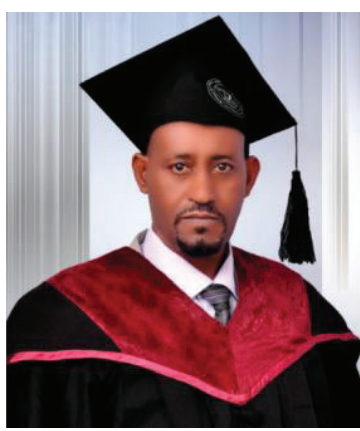

Abiy Serawitu Kassaye

Dire Dawa Management and Kaizen

Instit

(PhD Candidate) 